\title{
Potential for Potable Water Savings Due to Rainwater Use in a Precast Concrete Factory
}

\author{
Giovanna Bertuzzi and Enedir Ghisi *iD \\ Laboratory of Energy Efficiency in Buildings, Department of Civil Engineering, \\ Federal University of Santa Catarina, Florianópolis, SC 88040-900, Brazil; giovannakbertuzzi@gmail.com \\ * Correspondence: enedir.ghisi@ufsc.br; Tel.: +55-48-3721-2115; Fax: +55-48-3721-5191
}

\section{check for}

updates

Citation: Bertuzzi, G.; Ghisi, E. Potential for Potable Water Savings Due to Rainwater Use in a Precast Concrete Factory. Water 2021, 13, 448. https://doi.org/10.3390/w13040448

Academic Editors: Fernando A.

L. Pacheco and Warish Ahmed

Received: 4 January 2021

Accepted: 5 February 2021

Published: 9 February 2021

Publisher's Note: MDPI stays neutral with regard to jurisdictional claims in published maps and institutional affiliations.

Copyright: (c) 2021 by the authors. Licensee MDPI, Basel, Switzerland. This article is an open access article distributed under the terms and conditions of the Creative Commons Attribution (CC BY) license (https:/ / creativecommons.org/licenses/by/ $4.0 /)$.

\begin{abstract}
The objective of this paper was to assess the potential for potable water savings due to rainwater use in a precast concrete factory in southern Brazil. The economic feasibility and the rainwater quality were also assessed. The current water consumption, future water demand, and rainwater demand in the factory were estimated. The future demand considered was two times higher than the current water consumption since there were plans to increase the production. Three scenarios were then simulated using the computer programme Netuno. The ideal rainwater tank capacity, the potential for potable water savings, and the economic feasibility analysis for each scenario were estimated. Samples of rainwater were collected in the factory and tested for quality for manufacturing precast concrete. For a rainwater tank capacity equal to 25,000 L, the potential for potable water savings for the first scenario was $55.4 \%$, but the first scenario was considered economically unfeasible. For the same tank capacity, the second and third scenarios presented viable results regarding potable water savings and payback. As for the rainwater quality, it was proven to be adequate for manufacturing precast concrete. The main conclusion was that rainwater can be used to manufacture precast concrete in the factory studied herein.
\end{abstract}

Keywords: rainwater harvesting; rainwater quality; precast concrete; financial analysis; computer simulation

\section{Introduction}

Rainwater harvesting systems may be installed in different kinds of buildings, such as houses, commercial and residential buildings, factories, and many others. The economic benefit of the installation of the system is still a matter of concern among specialists. The economic feasibility varies significantly for each region, being highly dependent on the water tariff charged by the local water company, the rainfall, and the adequate sizing of the rainwater tanks [1].

A study carried out by Ghisi and Schondermark [2] about the installation of rainwater harvesting systems in houses in the state of Santa Catarina (Brazil) showed that the economic benefits of these systems depend on the water demand. Although there would be environmental benefits due to the installation of rainwater harvesting systems in all houses, there would be economic feasibility only in those with higher water demands or a higher number of occupants.

The use of rainwater can also be applied to situations that demand low volumes of water. Fernandes et al. [3] projected a rainwater harvesting system in a waste treatment installation close to the city of Mirandela (Portugal). Rainwater would be used to wash cars and other equipment, clean outdoor concrete and asphalt floors, and irrigate green areas. Fernandes et al. [3] pointed out that for installations that demand small amount of water, the water harvesting systems would be efficient even if the tank capacity did not supply $100 \%$ of the demand. The tank capacity supplied $90 \%$ of the water demand.

After going through adequate treatment, rainwater can be used in different applications that do not require potable water. The Brazilian standard NBR 15527 [4] presents 
some possibilities for the utilisation of rainwater, such as toilet flushing; water mirrors; irrigation of lawns and ornamental plants; washing cars; cleaning sidewalks, streets, and patios; and also for some industrial processes.

Rainwater harvesting systems and other measures that favour the preservation of the environment and natural resources are still rarely used in the field of civil construction. Zhang et al. [5] pointed out that it is likely that one of the main reasons construction companies have a low rate of adoption of environmental measures is because the financial savings are usually enjoyed by the building occupants and not necessarily by the constructor or the client that hired the construction.

A high amount of water is used in constructions, which shows the need for implementing programmes of sustainable use of water resources in construction sites [6]. As pointed out by Santos et al. [7], some studies on water use in buildings have already been performed; however, the water consumption in the stages of construction has been poorly explored. Souza and Ghisi [8] analysed 10 construction sites in Criciúma, southern Brazil, and observed that the average daily water consumption per worker was $51.25 \mathrm{~L} /$ worker.day (ranging from 42.73 to $65.58 \mathrm{~L} /$ worker.day), and the average monthly water consumption per built area was $5.06 \mathrm{~L} / \mathrm{m}^{2}$.month (ranging from 1.76 to $9.79 \mathrm{~L} / \mathrm{m}^{2}$.month). According to McCormack et al. [9], the efforts for reducing water consumption are mostly related to the operation of the building. Thus, the consumption of water for constructing buildings is usually neglected.

Zhong and $\mathrm{Wu}[10]$ performed a study in Singapore to investigate the performance of reinforced concrete and steel structures according to economic sustainability, environmental sustainability, and constructability. The results indicated that reinforced concrete structures consume approximately $1468 \mathrm{~L} / \mathrm{m}^{2}$ on average, while steel structures consume only $1.89 \mathrm{~L} / \mathrm{m}^{2}$. This difference is due to the differences in the construction process of these two types of structures. It was found that the consumption of water is not a decisive factor for the selection of the material used in the structure of the building.

Concrete is one of the materials largely used in the construction industry. It is necessary to use cement, coarse aggregate, fine aggregate, and water to manufacture concrete. Due to the high consumption of water in concrete mixing plants, precast concrete industries and construction sites are concerned with the consumption of this natural resource. In order to reduce the consumption of potable water for manufacturing concrete, there are some alternatives available, such as greywater or rainwater.

According to Arnaldo Forti Battagin (laboratory manager of the Brazilian Association of Portland Cement), rainwater can be used for manufacturing concrete, as long as it presents a $\mathrm{pH}$ higher than 5 and meets the requirements of the Brazilian standard NBR 15900 [11]. The Brazilian regulation about water for manufacturing concrete-NBR 15900 [12] — states that rainwater can be used for manufacturing concrete provided that it is tested for some parameters.

Bedoya-Montoya and Medina-Restrepo [13] conducted a study in Colombia to compare the quality of concrete produced using either potable water or rainwater. The authors installed a rainwater collection system on the campus of Institución Universitaria Colegio Mayor de Antioquia. The quality of the rainwater collected was monitored for six months. The water was analysed when the tank was full. The amount of water collected during the first five minutes of each rain was disposed of due to its lower quality. The potable water analysed was collected directly from the aqueduct supplied by the local water company. It was possible to identify that both were adequate to be used for manufacturing concrete. Afterwards, concrete specimens were submitted to compressive strength testing. The results obtained with the compressive strength testing did not indicate that the rainwater reduced the concrete strength in comparison with the samples manufactured using potable water. Bedoya-Montoya and Medina-Restrepo [13] also pointed out that there were no noticeable differences between the two samples of fresh concrete, regarding the laying process, workability, and appearance. 
The Brazilian regulation about water for manufacturing concrete, as well as the regulations of other countries, such as Colombia, allows for the utilisation of rainwater for manufacturing concrete, as long as the water meets the quality criteria established. However, using rainwater for manufacturing concrete is a subject that is still poorly explored globally, and the number of studies is still scarce.

The main objective of this paper was to assess the potential for potable water savings due to rainwater use in a precast concrete factory in southern Brazil. The economic feasibility and the rainwater quality were also assessed.

\section{Materials and Methods}

\subsection{The Factory}

The factory to be assessed is located in São José, southern Brazil. It currently has 65 employees and produces different kinds of concrete elements; the water demand is 15,000 L/d on average. The floor-plan areas of the main roofs of the factory sum $15,346.71 \mathrm{~m}^{2}$. Such a large roof area could be used to harvest rainwater. The roofs and their corresponding areas, A, are shown in Figure 1.

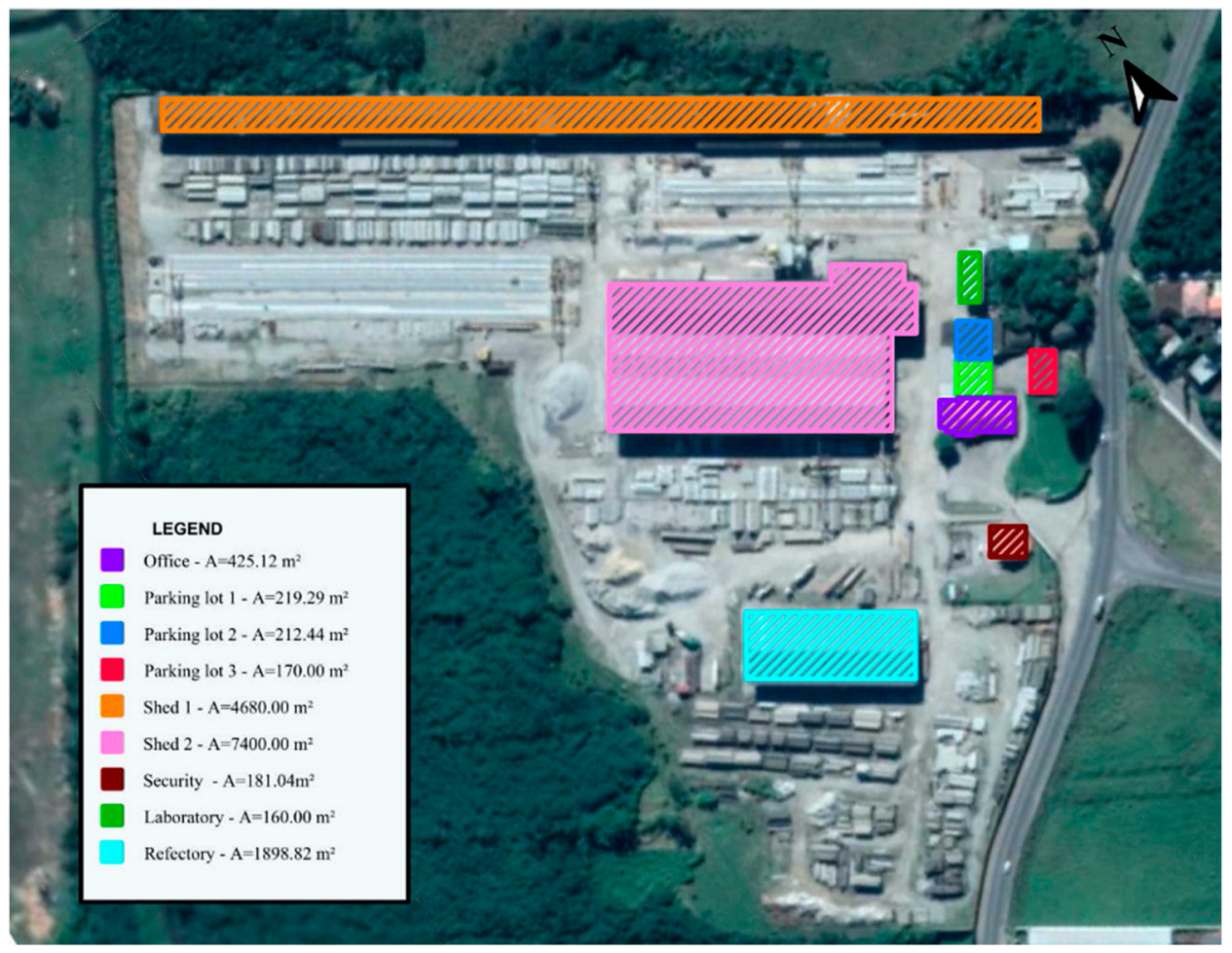

Figure 1. Layout of the roofs of the factory and their corresponding areas. Source: Image from Google Earth generated by the authors in 2018 .

\subsection{Data Collection}

In order to perform the analyses, we needed to collect some data, such as daily rainfall data. Furthermore, it was necessary to determine the water demand at the factory and to separate this demand into 2 categories. The first category is the one that requires potable water; the second is the one that does not require potability and therefore can be replaced with rainwater. Moreover, other types of data were essential to obtain the potential for potable water savings, such as the roof areas where the rainwater was collected and their runoff coefficients. 


\subsubsection{Rainfall Data}

The daily rainfall data used in this work were obtained from INMET [14] and are available on BDMEP (Meteorological Database for Teaching and Research). The weather station is located in the district of Praia Comprida in the city of São José (Latitude $27.6025^{\circ} \mathrm{S}$ and Longitude $48.620278^{\circ} \mathrm{W}$ ). This rainfall station was chosen due to its proximity to the factory $(3.5 \mathrm{~km})$ and because it has been operating since 1921 .

\subsubsection{Current Water Consumption}

It was not possible to obtain the total water consumption in the factory with accuracy because currently the water consumed is extracted from an artesian well located in situ, and therefore there is no control of the amount of water pumped daily or monthly. For this reason, water consumption at the factory was estimated. In order to estimate the water consumption, we needed to obtain the number of employees and activities that require water. For each activity, the consumption of water per unit (repetitions, $\mathrm{m}^{3}$, etc.) was estimated. The number of repetitions of each process and the volume of concrete manufactured were obtained from the reports kept at the factory.

The number of concrete elements produced varies throughout the year. It depends on the demand, but mainly on the factory planning since a great number of elements are produced to maintain the stock. Therefore, the total water consumption was estimated for each month of the year. The estimated water consumption was divided among the working days of the year since the factory only operates on those days.

\subsubsection{Rainwater Demand}

Currently, the artesian well is being used close to its maximum capacity. Therefore, in case the demand for water increases, it would be necessary to use water from the local water company, which increases costs. Since the company board is planning on doubling the monthly production of concrete elements, demanding a volume of water that is higher than the one available in the artesian well, the future water demand considered herein is twice as much the current consumption.

The volume of water available in the well varies according to rainfall and other environmental factors. Thus, the volume of water available daily varies throughout the year. For this reason, the average water consumption was considered. The average daily water extraction from the well was considered as $14,000 \mathrm{~L}$. This average figure was given by the factory managers, which obtained it throughout the years of the artesian well exploration.

Consequently, the rainwater demand considered was the figure that exceeds the average limit of exploration of the well. This way, on the days in which the future demand was lower than 14,000 L, there was no demand for rainwater. For the days in which the future demand surpasses the average limit of exploration of the well, the rainwater demand will be the future water demand minus 14,000 L. This was chosen to prioritise the use of water from the artesian well since it does not imply costs for acquisition, only costs with electricity for pumping the water.

\subsubsection{Runoff Coefficients}

The roofs which were considered to be a part of the rainwater harvesting system are made of different materials, such as ceramic, enamelled, and metallic tiles. The Brazilian standard NBR 15527 [4] presents runoff coefficients equal to 0.8 as the most commonly used. For this reason, 0.8 was adopted as the runoff coefficient for the factory roofs.

\subsection{Potential for Potable Water Savings}

The potential for potable water savings due to the installation of the rainwater harvesting system was estimated using the Netuno computer programme, version 4 [15]. Such savings refer to the savings of potable water supplied by the local water company since water savings from the artesian well are not desired by the company board. In order to 
estimate the potential for potable water savings using Netuno, we needed to obtain daily rainfall data, as well as some other data such as first flush, rainwater catchment area, total water demand, number of occupants, rainwater demand, and the runoff coefficient of the roofs.

The installation of a lower-level rainwater tank and an upper-level tank was considered. The rainwater collected from the roofs would be stored in the lower-level tank, and then pumped to the upper-level tank, allowing the rainwater distribution for consumption to be done by gravity.

The capacity of the upper-level rainwater tank was also input data for the simulations. As for the lower-level rainwater tank, different capacities were simulated. The upper-level rainwater tank was considered to be installed at roof level, and the lower-level rainwater tank was to be placed at ground level. Different roof areas were also simulated. Three scenarios were considered in order to allow the comparison of different levels of investment in rainwater harvesting according to the roof area used to harvest rainwater. In the first scenario, rainwater was collected from all roofs identified in Figure 1; in the second scenario, all roofs but sheds 1 and 2 were considered; and in the third scenario, all roofs but shed 1 and the refectory were considered.

The Netuno computer programme estimates the potential for potable water savings for each lower-level rainwater tank. Netuno's main output data are potential for potable water savings; daily rainwater consumption; percentage of days in a year in which the rainwater demand is fully met, partially met, and not met; and the ideal capacity for the lower-level rainwater tank. More information about the Netuno computer programme algorithm can be found in Ghisi [16].

\subsection{Financial Analysis}

In order to perform the financial analysis for the three scenarios, we required some estimations. The quantity and the diameters necessary for gutters; piping; pipe connections; rainwater tank; and other accessories such as solenoid valve and float switch, among others, were estimated.

The financial analysis was performed using Netuno. The water and sewage tariffs, the monthly inflation, the period in which water and electricity tariffs increase, the period of analysis, and the minimum acceptable rate of return were some of the input data. Moreover, labour costs and the costs of the rainwater tanks, piping, and accessories were needed. When an upper-level water tank was used, the electricity tariffs and the costs of the upper-level rainwater tank and the motor pump were also necessary. Furthermore, other operational costs may need to be considered, such as costs with maintenance or water treatment, when applicable.

The inflation considered was the average of the monthly inflation between October 2017 and September 2018, obtained from the National Index of Prices for the Wide Consumer (IPCA) from the Brazilian Institute of Geography and Statistics [17]. The water tariffs for consumption in industries were obtained from the local water company, and the sewage tariffs were considered null since the factory has its sewage treatment systems in situ. The electricity tariffs were obtained from the local electricity company. Taxes were also considered. The period of readjustment of water and electricity tariffs was considered as 12 months.

The period of analysis considered was 20 years, which is the average lifespan of the motor pump - the equipment of the system that has the shortest lifespan. The minimum acceptable rate of return considered was the average profitability index of the savings account between October 2017 and September 2018.

The net present value, internal rate of return, and discounted payback were obtained using Netuno. The scenarios were considered economically feasible when the internal rate of return was higher than the minimum acceptable rate of return, and the net present value was positive. 
The net present value can be estimated using Equation (1) [18].

$$
N P V=C_{0}+\frac{C_{1}}{1+i}+\frac{C_{2}}{(1+i)^{2}}+\ldots+\frac{C_{n}}{(1+i)^{\mathbf{n}}}
$$

where $N P V$ is the net present value (R\$, which stands for Brazilian Real (BRL)), $C_{n}$ is the net cash flow at the period $n$, and $i$ is the minimum acceptable rate of return. The period considered for the financial analysis ( $n$ ) was 240 months (20 years). All costs were considered as negative figures and the savings as positive figures. $C_{0}$ was calculated considering the costs of the lower-level rainwater tank, the upper-level rainwater tank, labour, piping, accessories, and pumps. The costs considered for $C_{1}$ to $C_{20}$ included the electricity tariff and corresponding taxes for the operation of the pump.

The payback period represents the time when the invested capital is recovered. It is considered that the investment is recovered when the net present value becomes zero. Therefore, the payback period is the value $n$ in Equation (1) when NPV is equal to zero.

The discount rate that results in a net present value equal to zero, considering the period for the financial analysis, is the internal rate of return. The internal rate of return represents the profitability of the investment and can be obtained using Equation (2) (based on Mishan and Quah [19]).

$$
\mathbf{0}=\sum_{\mathbf{t}=0}^{\mathbf{n}} \frac{C_{n}}{(\mathbf{1}+\mathbf{I} R \boldsymbol{R})^{\mathbf{n}}}
$$

where IRR is the internal rate of return (\% per month); $C_{n}$ is the net cash flow at the period $n$; and $n$ is the period considered for the financial analysis, which was 240 months.

\subsection{Rainwater Quality}

In this study, rainwater is meant to be used only for manufacturing concrete, cutting pieces, and cleaning lanes. Two rainwater samples were collected in two different days from the same location, i.e., the roof of the office. In the first sample, there was no first flush disposal, and in the second, there was first flush disposal. The objective was to compare the quality of the rainwater collected in 2 different situations. The first sample was collected on the 11 September 2018, after 6 days with no rain. The second sample was collected on the 12 September 2018 and there was a first flush disposal equal to $2 \mathrm{~mm}$. The procedure for collecting and storing the samples complied with NBR 15900 [12].

The rainwater quality was assessed according to NBR 15900 [12]. First of all, it was necessary to perform the preliminary tests. After that, if the water met the requirements established for the preliminary tests, the determination of contaminants (sugars, phosphates, nitrates, lead, and zinc) could be made. In case the water was not approved in the criteria established for the preliminary tests, the concrete setting time and concrete strength tests would be mandatory. If the water being tested did not meet all the criteria established for the preliminary tests, it could still be approved for use in concrete, as long as it was approved in the tests of concrete setting time and concrete strength, chlorides (or meet the requirements of NBR 12655 [20]), sulphate, and alkalis (or meet the requirements of NBR 15577 [21]). We chose to perform the preliminary tests and also the concrete setting time and concrete strength tests regardless of the results of the preliminary tests. By performing these tests, the determination of contaminants would not be necessary.

Afterwards, it was necessary to perform the tests for chlorides and sulphate. The determination of the level of alkalis was not necessary since aggregates not reactive with alkalis are used in the factory. The factory uses aggregates from a single supplier, obtained from the same mine, and the non-reactivity of the material is verified using periodic tests for the alkali-aggregate reaction.

Therefore, the following tests were performed: (i) preliminary tests: oils and fat, detergents, colour, solid material, odour, acids ( $\mathrm{pH})$, organic matter; (ii) concrete setting time; (iii) concrete strength; (iv) chlorides; (v) sulphate. 
The preliminary tests and the tests for the level of chlorides and sulphate were performed in duplicate in the Integrated Laboratory of the Environment (LIMA) in the Department of Sanitary and Environmental Engineering of the Federal University of Santa Catarina (UFSC). The oils and fats, detergents, colour, solid material, and odour tests were performed according to the procedures indicated in the NBR 15900 [12].

The test for acid levels $(\mathrm{pH})$ was performed using a piece of $\mathrm{pH}$-meter equipment, which is an instrument used to measure the $\mathrm{pH}$ through the potentiometric method. The organic matter tests were performed using the colourimetric method. The concrete setting time test was performed in the Laboratory of Civil Construction Materials (LMCC) in the Civil Engineering Department of the Federal University of Santa Catarina (UFSC) according to the procedure indicated in the NBR 16607 [22]. The standard NBR 15900 [12] defines that for the water sample to be approved in the concrete setting time criteria, the beginning and the end of the concrete setting time must not differ more than $25 \%$ from the beginning and the end of the concrete setting time of paste prepared with distilled or deionised water. The beginning and end of the concrete setting time must also meet the criteria established in the Brazilian regulation for the cement used. In this case, the cement used was the CP IV 32.

The strength tests were performed in the laboratory in the factory. In order to perform the concrete strength tests, we moulded concrete specimens according to the criteria established in NBR 5738 [23]. The specimens were ruptured at 7 and 28 days, according to the procedure stated in NBR 5739 [24]. The concrete mix used for all the specimens was the same, which was the standard mix used in the factory. The cement used was the CP V ARI. The test for chlorides in the water samples was performed using the procedure of titulometry. NBR 15900 [12] establishes limits for the chloride levels in the tested water according to the use intended for the concrete. The possible uses are precast concrete or grout, reinforced concrete, and standard concrete. Precast concrete elements and reinforced concrete elements are manufactured at the factory. Since the maximum level of chloride for precast concrete is the lowest (stricter), the maximum limit of chloride level considered was defined for this category, this being $500 \mathrm{mg} / \mathrm{L}$.

The sulphate test was performed using a spectrophotometer with a wavelength of $420 \mathrm{~nm}$. The maximum level of acceptance for sulphate in the water is established in NBR 15900 [12] as $2000 \mathrm{mg} / \mathrm{L}$.

\section{Results and Discussion}

\subsection{Rainfall Data}

Daily rainfall data from September 2001 to July 2018-approximately 17 years of data-were used in the analysis. The annual rainfall over 2002 and 2017 is shown in Figure 2. The average annual rainfall over that period was $1775 \mathrm{~mm}$. The average monthly rainfall, as well as the minimum and maximum for each month, are shown in Figure 3. The month with the highest rainfall was January $(223 \mathrm{~mm})$; the lowest was June $(85 \mathrm{~mm})$. Although rainfall distribution is not homogeneous along the year, long dry periods were not observed, which indicates that it is possible to collect rainwater during all seasons of the year. 


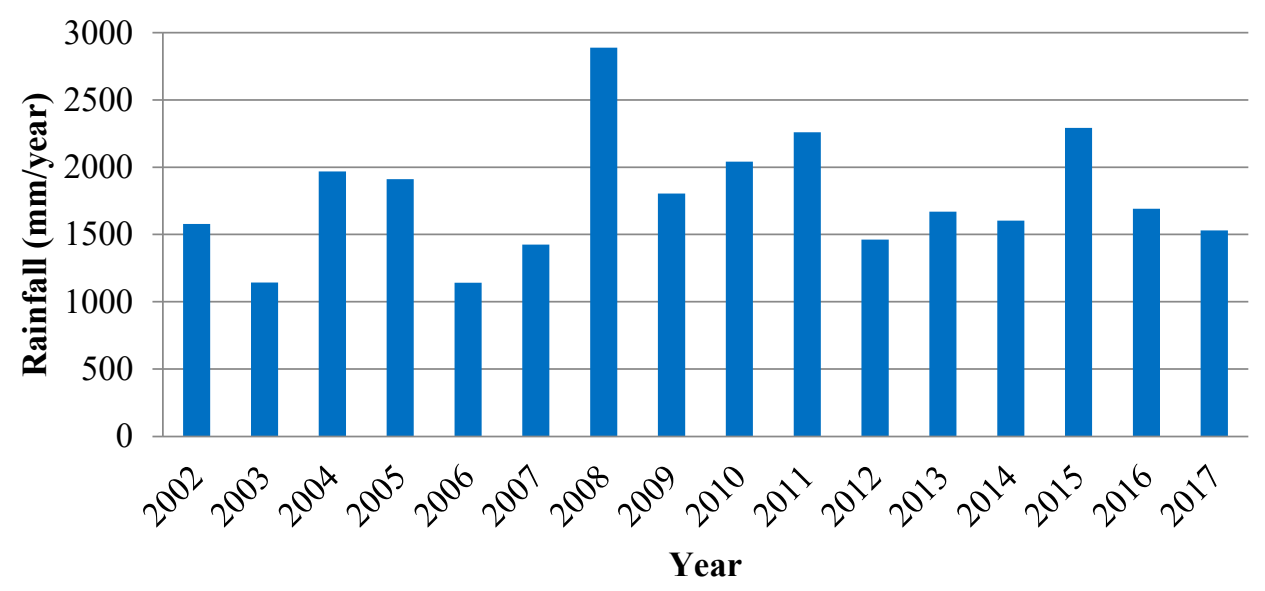

Figure 2. Annual rainfall in the city of São José over 2002-2017. Source: Based on INMET [14].

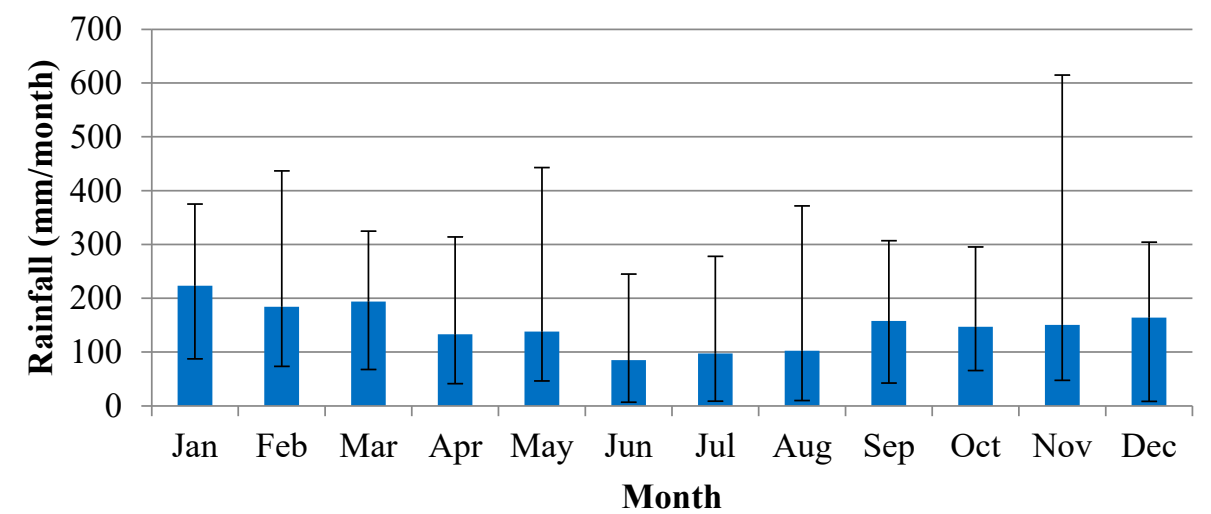

Figure 3. Average, minimum, and maximum monthly rainfall in the city of São José over 2002-2017. Source: Based on INMET [14].

\subsection{Current Water Consumption}

The estimates for water consumption in the factory are shown in Table 1. Total water consumption ranged from around $74,000 \mathrm{~L}$ to $391,000 \mathrm{~L}$ per month.

Table 1. Water consumption at the factory from August 2017 to July 2018.

\begin{tabular}{|c|c|c|c|c|c|c|}
\hline Month/Year & $\begin{array}{c}\text { Water for } \\
\text { Manufacturing } \\
\text { Concrete } \\
\text { (L/month) }\end{array}$ & $\begin{array}{l}\text { Water for } \\
\text { Cutting and } \\
\text { Cleaning } \\
\text { Lanes } \\
\text { (L/month) }\end{array}$ & $\begin{array}{l}\text { Water for } \\
\text { Human } \\
\text { Consumption } \\
\text { (L/month) }\end{array}$ & $\begin{array}{l}\text { Total Water } \\
\text { Consumption } \\
\text { (L/month) }\end{array}$ & $\begin{array}{c}\text { Working Days } \\
\text { in the Month } \\
\text { (Days) }\end{array}$ & $\begin{array}{c}\text { Daily Average } \\
\text { Consumption } \\
\text { on Working } \\
\text { Days (L/d) }\end{array}$ \\
\hline August/2017 & 309,116 & 34,400 & 47,840 & 391,356 & 23 & 17,015 \\
\hline September/2017 & 96,354 & 800 & 41,600 & 138,754 & 20 & 6938 \\
\hline October/2017 & 101,884 & 16,250 & 43,680 & 161,814 & 21 & 7705 \\
\hline November/2017 & 186,462 & - & 41,600 & 228,062 & 20 & 11,403 \\
\hline December/2017 & 148,686 & - & 41,600 & 190,286 & 20 & 9514 \\
\hline January/2018 & 25,773 & 2500 & 45,760 & 74,033 & 22 & 3365 \\
\hline February/2018 & 176,370 & 24,850 & 39,520 & 240,740 & 19 & 12,671 \\
\hline March/2018 & 100,641 & 9700 & 43,680 & 154,021 & 21 & 7334 \\
\hline April/2018 & 93,402 & 17,750 & 43,680 & 154,832 & 21 & 7373 \\
\hline May/2018 & 147,459 & 2800 & 45,760 & 196,019 & 22 & 8910 \\
\hline June/2018 & 213,106 & 20,300 & 43,680 & 277,086 & 21 & 13,195 \\
\hline July/2018 & 227,282 & 18,650 & 45,760 & 291,692 & 22 & 13,259 \\
\hline
\end{tabular}




\subsection{Rainwater Demand}

The water demand considered for the analysis was twice as high as the current water consumption. The total water consumption in the factory can be divided into two categories: potable water and non-potable water. The non-potable water is related to the uses for manufacturing concrete, cutting elements, and cleaning lanes since these activities do not require potable water. The potable water is used for human consumption. The non-potable water demand is the one that can be replaced with rainwater. The total water demand is shown in Table 2.

Table 2. Total water demand at the factory.

\begin{tabular}{|c|c|c|c|c|c|c|}
\hline Month & $\begin{array}{c}\text { Water for } \\
\text { Manufacturing } \\
\text { Concrete } \\
\text { (L/month) }\end{array}$ & $\begin{array}{l}\text { Water for } \\
\text { Cutting and } \\
\text { Cleaning } \\
\text { Lanes } \\
\text { (L/month) }\end{array}$ & $\begin{array}{l}\text { Water for } \\
\text { Human } \\
\text { Consumption } \\
\text { (L/month) }\end{array}$ & $\begin{array}{l}\text { Total Water } \\
\text { Demand } \\
\text { (L/month) }\end{array}$ & $\begin{array}{l}\text { Working Days } \\
\text { in the Month } \\
\text { (Days) }\end{array}$ & $\begin{array}{l}\text { Daily Average } \\
\text { Demand on } \\
\text { Working Days } \\
\text { (L/d) }\end{array}$ \\
\hline January & 51,547 & 5000 & 91,520 & 148,067 & 22 & 6730 \\
\hline February & 352,740 & 49,700 & 79,040 & 481,480 & 19 & 25,341 \\
\hline March & 201,283 & 19,400 & 87,360 & 308,043 & 21 & 14,669 \\
\hline April & 186,805 & 35,500 & 87,360 & 309,665 & 21 & 14,746 \\
\hline May & 294,918 & 5600 & 91,520 & 392,038 & 22 & 17,820 \\
\hline June & 426,211 & 40,600 & 87,360 & 554,171 & 21 & 26,389 \\
\hline July & 454,564 & 37,300 & 91,520 & 583,384 & 22 & 26,517 \\
\hline August & 618,232 & 68,800 & 95,680 & 782,712 & 23 & 34,031 \\
\hline September & 192,708 & 1600 & 83,200 & 277,508 & 20 & 13,875 \\
\hline October & 203,768 & 32,500 & 87,360 & 323,628 & 21 & 15,411 \\
\hline November & 372,925 & - & 83,200 & 456,125 & 20 & 22,806 \\
\hline December & 297,372 & - & 83,200 & 380,572 & 20 & 19,029 \\
\hline
\end{tabular}

The volume of water available in the artesian well varies according to the time of the year due to various environmental factors. In order to analyse the potential for potable water savings through the implementation of a rainwater harvesting system, we used an average value provided by the factory managers. The amount of water obtained from the artesian well was 14,000 L/d.

The future water demand will be supplied by three different sources: water from the artesian well, water from the water company, and rainwater. When the daily demand is equal to or lower than $14,000 \mathrm{~L}$, it is fully met by the water in the artesian well. When the daily demand is greater than $14,000 \mathrm{~L}$, the exceeding demand is supplied with rainwater, and when the rainwater cannot fully supply the exceeding demand, the demand is met with water from the water company. Thus, the daily demand for potable purposes (which is $4160 \mathrm{~L} / \mathrm{d}$ ) is fully supplied by the artesian well.

Table 3 shows the water demand that can be supplied with rainwater, representing the amount that exceeds the 14,000 L of daily consumption. Figure 4 shows the amount of water that can be supplied by the artesian well, as well as the amount of water that will be supplied with water from the water company and that can be replaced with rainwater. 
Table 3. Water demand that can be replaced with rainwater.

\begin{tabular}{cc}
\hline Month & Water Demand on Working Days That Can Be Replaced with Rainwater (L/d) \\
\hline January & - \\
February & 11,341 \\
March & 669 \\
April & 746 \\
May & 3820 \\
June & 12,389 \\
July & 12,517 \\
August & 20,031 \\
September & - \\
October & 1411 \\
November & 8806 \\
December & 5029 \\
\hline
\end{tabular}

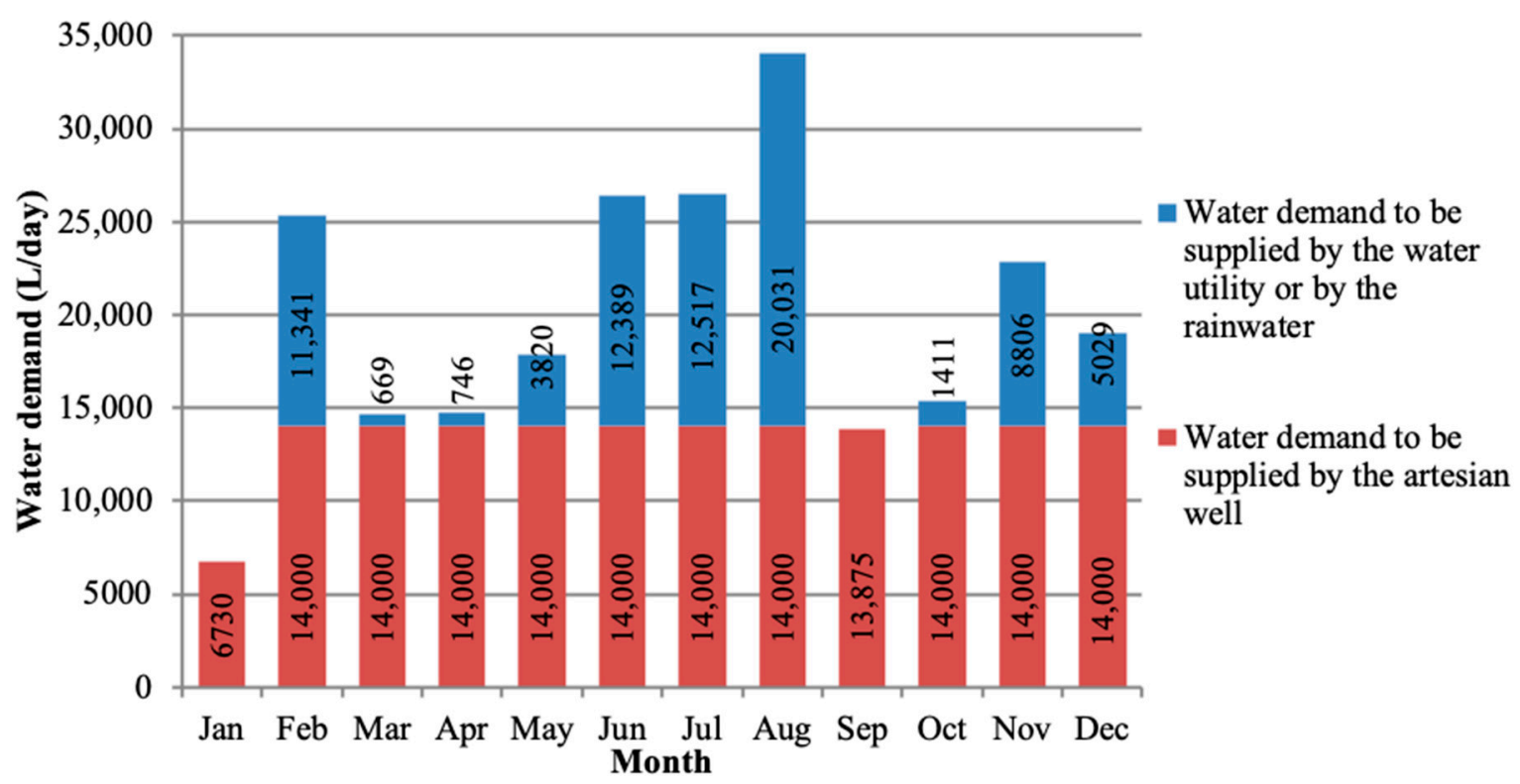

Figure 4. Water demand that can be supplied either by the artesian well and the water company or rainwater.

\subsection{Potential for Potable Water Savings}

After defining the water demand that can be replaced with rainwater, we performed simulations using Netuno to determine the ideal rainwater tank capacity. Simulations were run for three scenarios, as explained in Section 2. The input data for the three scenarios are shown in Table 4 . The daily water demand considered was the average daily demand on working days; the demand considered was null over weekends and holidays.

It was considered that the factory had only one occupant because the water demand was considered, taking into account the total number of employees and the water demand for all the other uses in the factory. It considered the installation of an upper-level rainwater tank of $5000 \mathrm{~L}$ so that the rainwater could be pumped from the lower-level rainwater tank to the upper one and then distributed by gravity. Both tanks were considered as being installed outside of the buildings. The potential for potable water savings was calculated for each scenario considering the ideal lower-level rainwater tank capacity obtained through the simulations and also the potential for potable water savings considering a lower-level tank capacity equal to $25,000 \mathrm{~L}$. The $25,000 \mathrm{~L}$ capacity was chosen because it is adequate for any of the three scenarios and it can be easily found on the market. The results obtained from the simulations for the three scenarios are shown in Table 5. 
Table 4. Input data used in the Netuno computer programme.

\begin{tabular}{|c|c|c|}
\hline \multicolumn{3}{|c|}{ Input Data } \\
\hline Initial date & & \\
\hline First flush disposal (mm) & & \\
\hline Roof area $\left(\mathrm{m}^{2}\right)$ & First scenario: & $15,346.71$ \\
\hline & Second scenario: & 3266.71 \\
\hline & Third scenario: & 8767.89 \\
\hline Total water demand & \multicolumn{2}{|c|}{ Variable (according to data shown in Table 3) } \\
\hline Number of occupants & \multicolumn{2}{|c|}{1} \\
\hline Rainwater demand ( $\%$ of the total water demand) & \multicolumn{2}{|c|}{100} \\
\hline Runoff coefficient & \multicolumn{2}{|c|}{0.8} \\
\hline Capacity of the upper-level rainwater tank (L) & \multicolumn{2}{|c|}{5000} \\
\hline $\begin{array}{c}\text { Percentage of the upper-level rainwater tank volume in } \\
\text { which there is pumping from the lower-level to the } \\
\text { upper-level tank (\%) }\end{array}$ & \multicolumn{2}{|c|}{5} \\
\hline Capacity of the lower-level rainwater tank & \multicolumn{2}{|c|}{ Simulation for various capacities } \\
\hline Maximum capacity of the lower-level rainwater tank (L) & \multicolumn{2}{|c|}{50,000} \\
\hline Interval between capacities (L) & \multicolumn{2}{|c|}{1000} \\
\hline $\begin{array}{c}\text { Difference between potentials for potable water savings } \\
\text { through rainwater usage }\left(\% / \mathrm{m}^{3}\right)\end{array}$ & \multicolumn{2}{|c|}{1} \\
\hline
\end{tabular}

Table 5. Results obtained from the computer simulations.

\begin{tabular}{|c|c|c|c|}
\hline Item & First Scenario & Second Scenario & Third Scenario \\
\hline Ideal lower-level rainwater tank capacity (L) & 25,000 & 22,000 & 25,000 \\
\hline $\begin{array}{l}\text { Potential for potable water savings for the ideal } \\
\text { tank capacity }(\%)\end{array}$ & 55.4 & 47.4 & 54.6 \\
\hline $\begin{array}{l}\text { Potential for potable water savings considering a } \\
\text { lower-level tank capacity equal to } 25,000 \mathrm{~L}(\%)\end{array}$ & 55.4 & 50.2 & 54.6 \\
\hline $\begin{array}{l}\text { Reliability considering a lower-level tank } \\
\text { capacity equal to } 25,000 \mathrm{~L} \text { (\% of days in a year in } \\
\text { which the rainwater demand is fully met) }\end{array}$ & 41.91 & 39.06 & 41.53 \\
\hline
\end{tabular}

The results obtained for the three scenarios showed that even though the roof area variation was significant, it did not greatly impact the ideal lower-level rainwater tank capacity, the potential for potable water savings, or the reliability.

\subsection{Financial Analysis}

The cost of labour was obtained by consulting specialised companies in the region; it was estimated as BRL 75,000 for the first scenario, BRL 18,000 for the second scenario, and BRL 25,000 for the third scenario.

The costs of the rainwater harvesting systems for the three scenarios are shown in Table 6 . The cost of accessories refers to equipment such as gutters, piping connections, float switches, solenoid valves, and other necessary items for the system.

Table 6. Costs for implementing the scenarios.

\begin{tabular}{cccc}
\hline \multirow{2}{*}{ Component } & \multicolumn{3}{c}{ Cost (BRL) } \\
\cline { 2 - 4 } & First Scenario & Second Scenario & Third Scenario \\
\hline Upper-level rainwater tank & 1799 & 1799 & 1799 \\
Lower-level rainwater tank & 7544.72 & 7544.72 & 7544.72 \\
Labour costs & $75,000.00$ & $18,000.00$ & $25,000.00$ \\
Piping & $116,449.02$ & $29,627.59$ & $33,998.05$ \\
Accessories & $112,084.86$ & $22,013.36$ & $50,456.06$ \\
Pumps (1 HP) & 1659.80 & 1659.80 & 1659.80 \\
Total & $314,537.40$ & $80,644.47$ & $120,457.63$ \\
\hline
\end{tabular}


For the financial analysis, the data shown in Table 7 were used as input data to Netuno. The results for the financial analysis simulated using Netuno are shown in Table 8.

Table 7. Input data for the financial analysis.

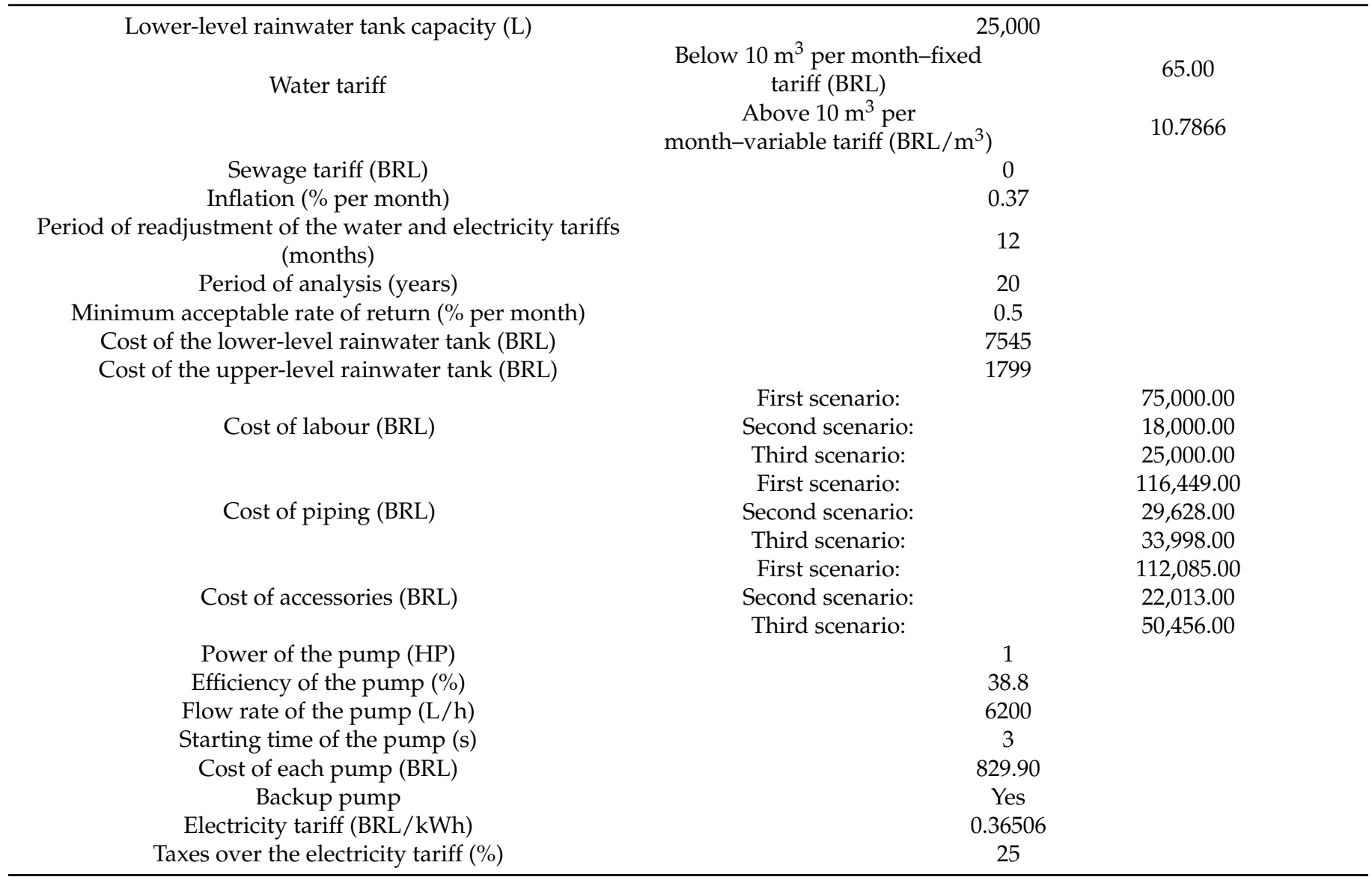

Table 8. Results of the financial analysis.

\begin{tabular}{cccc}
\hline Indicator & First Scenario & Second Scenario & Third Scenario \\
\hline Net present value (BRL) & $-155,247.12$ & $61,207.27$ & $33,740.93$ \\
Discounted payback period (months) & - & 127 & 181 \\
Internal rate of return (\%/month) & -0.05 & 1.07 & 0.73 \\
\hline
\end{tabular}

In analysing the results, we noticed that the first scenario did not present economic feasibility. This happened because the installation of gutters and pipes was considered in all roofs in this scenario. Thus, the initial costs were much higher than the costs for the two other scenarios. On the other hand, the potential for potable water savings was not much higher than the two other scenarios. The second and third scenarios were economically feasible. Even though the second scenario presented the lowest payback, it was the scenario that presented the lowest potential for potable water savings.

\subsection{Rainwater Quality}

The possibility of using rainwater for the production and cutting concrete pieces and cleaning lanes was considered. In order to consider the use of rainwater to manufacture concrete as viable, we needed to perform some analyses in samples of rainwater collected in situ. The objective of such analyses was to evaluate whether the rainwater was adequate for manufacturing concrete and did not affect its strength or durability. 
Tests were performed for four samples of rainwater collected at the same place but on different days. The first collection was performed for two samples with no first flush disposal; meanwhile, the second collection was performed for two other samples considering a first flush disposal equal to $2 \mathrm{~mm}$.

The results obtained from the preliminary tests are shown in Table 9. Average results are shown for the quantity analysis. The rainwater from the second collection was approved in all the requirements established in NBR 15900 [12]. However, the first collection did not meet the criteria on the presence of organic matter, even though it was approved according to the other preliminary analysis criteria. If a sample is not approved in these criteria, it does not mean that such rainwater cannot be used for manufacturing concrete. Such rainwater can still be used, as long as it is approved in the concrete setting time test and the concrete strength test.

Table 9. Results from the preliminary tests.

\begin{tabular}{|c|c|c|c|}
\hline Test & Requirement & First Rainwater Collection & Second Rainwater Collection \\
\hline Oils and fats & No more than visible traces & Oils and fats were not found & Oils and fats were not found \\
\hline Detergents & $\begin{array}{l}\text { Any visible foam must disappear in } \\
\qquad 2 \mathrm{~min}\end{array}$ & $\begin{array}{c}\text { No foam was observed after } 2 \text { min of } \\
\text { rest }\end{array}$ & $\begin{array}{c}\text { No foam was observed after } 2 \text { min of } \\
\text { rest }\end{array}$ \\
\hline Colour & Light yellow to colourless & Colourless & Colourless \\
\hline $\begin{array}{l}\text { Solid material } \\
(\mathrm{mg} / \mathrm{L})\end{array}$ & Maximum of $50,000 \mathrm{mg} / \mathrm{L}$ & 52 & 56 \\
\hline Odour & $\begin{array}{c}\text { The water must be odourless and } \\
\text { must not present hydrogen sulphide } \\
\text { odour after the addition of } \\
\text { hydrochloric acid }\end{array}$ & $\begin{array}{l}\text { Odourless and did not present } \\
\text { hydrogen sulphide odour after the } \\
\text { addition of hydrochloric acid }\end{array}$ & $\begin{array}{l}\text { Odourless and did not present } \\
\text { hydrogen sulphide odour after the } \\
\text { addition of hydrochloric acid }\end{array}$ \\
\hline Acids (pH) & $\geq 5$ & 6.44 & 6.23 \\
\hline $\begin{array}{l}\text { Organic matter } \\
(\mathrm{mg} / \mathrm{L})\end{array}$ & $\begin{array}{c}\text { The colour of the water must be equal } \\
\text { or brighter than the standard solution } \\
\text { after the addition of } \mathrm{NaOH}\end{array}$ & 8.18 & 0 \\
\hline
\end{tabular}

The results of the concrete setting time and concrete strength tests are shown in Table 10, and the limits for acceptance of the concrete setting time and concrete strength tests are shown in Table 11.

Table 10. Results of the concrete setting time and concrete strength tests.

\begin{tabular}{ccccc}
\hline Sample & Distilled Water & $\begin{array}{c}\text { First Rainwater } \\
\text { Collection }\end{array}$ & $\begin{array}{c}\text { Second Rainwater } \\
\text { Collection }\end{array}$ & $\begin{array}{c}\text { Artesian Well } \\
\text { Water }\end{array}$ \\
\hline Start of setting (h) & $4: 00$ & $4: 20$ & $4: 10$ & - \\
End of setting (h) & $5: 30$ & $5: 40$ & $5: 40$ & - \\
Strength of CPI at 7 days (MPa) & 47.23 & 44.15 & 50.93 & 41.51 \\
Strength of CPII at 7 days (MPa) & 46.93 & 47.75 & 50.51 & 40.86 \\
Average strength at 7 days (MPa) & 47.08 & 45.95 & 50.72 & 41.18 \\
Strength CPI at 28 days (MPa) & 57.82 & 57.80 & 58.64 & 51.31 \\
Strength CPII at 28 days (MPa) & 57.16 & 60.06 & 58.53 & 54.66 \\
Average strength at 28 days (MPa) & 57.49 & 59.20 & 58.58 & 52.98 \\
\hline
\end{tabular}

Table 11. Limits for acceptance of the rainwater being tested.

\begin{tabular}{ccc}
\hline Criteria & Minimum Limit & Maximum Limit \\
\hline Start of setting (maximum difference of 25\% from the distilled water) (h) & $3: 00$ & $5: 00$ \\
End of setting (maximum difference of 25\% from the distilled water) (h) & $4: 08$ & $6: 52$ \\
Start of setting of CP IV 32 cement NBR 5739 [24] (h) & $1: 00$ & - \\
Limits for end of setting of CP IV 32 cement NBR 5739 [24] (h) & 42.37 & $12: 00$ \\
Concrete strength at 7 days (90\% of the distilled water strength) (MPa) & - \\
Concrete strength at 28 days (90\% of the distilled water strength) (MPa) & 51.74 & - \\
\hline
\end{tabular}


The limits for acceptance were calculated on the basis of the results for concrete manufactured using distilled water. The standard NBR 15900 [12] defines that concrete samples can be approved if the beginning and end of setting times present a maximum variation of $25 \%$ when compared to concrete produced using distilled water. As for the strength of the concrete specimens, the Brazilian standard defines that they must present a minimum strength of $90 \%$ of the strength of the concrete specimens produced using distilled water. By analysing the results, we were able to conclude that both rainwater samples were approved in the concrete setting time and concrete strength criteria, since the results meet the limits shown in Table 11. The water collected from the artesian well, which is used in the factory, has its potability assured by tests performed periodically. The standard NBR 15900 [12] considers that if the water potability is assured, it can be considered adequate for manufacturing concrete without the need for further testing. Thus, even though the concrete manufactured using water from the artesian well did not achieve $90 \%$ of the concrete strength of the concrete with distilled water, the water collected from the well can still be considered adequate for manufacturing concrete according to NBR 15900 [12].

The results of the chloride tests are shown in Table 12, and the results of the sulphate tests are shown in Table 13. Two samples from the first rainwater collection were tested, representing the rainwater with no first flush disposal. In order to test the chloride and sulphate levels in the second rainwater collection, which considered a $2 \mathrm{~mm}$ first flush disposal, we tested two other samples.

Table 12. Results of the levels of chloride.

\begin{tabular}{cccc}
\hline Source & $\begin{array}{c}\text { Level of Chloride in Sample } \\
\mathbf{1}(\mathbf{m g} / \mathrm{L})\end{array}$ & $\begin{array}{c}\text { Level of Chloride in Sample } \\
\mathbf{2}(\mathbf{m g} / \mathrm{L})\end{array}$ & $\begin{array}{c}\text { Average Level of Chloride } \\
(\mathbf{m g} / \mathrm{L})\end{array}$ \\
\hline $\begin{array}{c}\text { First rainwater collection } \\
\text { Second rainwater collection }\end{array}$ & 0 & 0 & 0 \\
\hline
\end{tabular}

Table 13. Results of the level of sulphate.

\begin{tabular}{cccc}
\hline Source & $\begin{array}{c}\text { Level of Sulphate in Sample } \\
\mathbf{1}(\mathbf{m g} / \mathrm{L})\end{array}$ & $\begin{array}{c}\text { Level of Sulphate in Sample } \\
\mathbf{2}(\mathbf{m g} / \mathrm{L})\end{array}$ & $\begin{array}{c}\text { Average Level of Sulphate } \\
(\mathbf{m g} / \mathrm{L})\end{array}$ \\
\hline First rainwater collection & 2.65 & 2.25 & 2.45 \\
Second rainwater collection & 2.43 & 2.55 & 2.49 \\
\hline
\end{tabular}

The standard NBR 15900 [12] establishes limits for the presence of chloride in the tested water according to the use intended for the concrete. The possible uses for concrete are precast concrete or grout, reinforced concrete, and standard concrete. The factory manufactures precast concrete and reinforced concrete elements. Since the maximum chloride level for precast concrete is lower (stricter), the maximum chloride limit adopted was the one defined for this concrete category, which is $500 \mathrm{mg} / \mathrm{L}$. As for the chloride levels, the rainwater from both the first and the second collection was approved.

The maximum level for acceptance of the tested rainwater for the presence of sulphate established in NBR 15900 [12] is $2000 \mathrm{mg} / \mathrm{L}$. Since the level of sulphate in the rainwater samples from the two collections was lower than the acceptable limit, both samples were approved in this criterion.

\section{Conclusions}

This paper investigated if rainwater could be used to manufacture precast concrete in a factory located in southern Brazil. The potential for potable water savings due to rainwater use as well as the economic feasibility analysis and the rainwater quality were assessed.

The budgets for the installation of the rainwater harvesting systems were estimated, and the economic feasibility of three scenarios was evaluated. The first scenario did not 
present economic feasibility; meanwhile, the payback period for the second scenario was 127 months, and for the third scenario it was 181 months (internal rates of return were 1.07 and $0.73 \%$ per month, respectively). For the economically feasible scenarios, the potential for potable water savings would range from $50.2 \%$ to $54.6 \%$.

The quality of the rainwater was also assessed through tests using rainwater samples collected from the roof of the factory. The samples met the requirements established by Brazilian standards. Thus, the rainwater collected was considered appropriate for manufacturing concrete and for cutting elements and cleaning lanes in the factory studied herein. However, we acknowledge that the rainwater quality should be assessed over a whole year.

In addition to being economically feasible, rainwater harvesting systems can promote the sustainable use of water and also contribute to increasing the impression of clients about the company. Companies which adopt sustainable strategies, such as the use of rainwater, have more visibility and show their clients that the company is concerned with reducing the impact on the environment.

Author Contributions: Supervision, E.G.; planning the experiments, G.B.; carrying out the experiments, G.B.; writing-review and editing, E.G. All authors have read and agreed to the published version of the manuscript.

Funding: This research received no external funding.

Institutional Review Board Statement: Not applicable.

Informed Consent Statement: Not applicable.

Data Availability Statement: Data are contained within the article.

Conflicts of Interest: The authors declare no conflict of interest.

\section{References}

1. Amos, C.C.; Rahman, A.; Gathenya, J.M. Economic Analysis and Feasibility of Rainwater Harvesting Systems in Urban and Peri-Urban Environments: A Review of the Global Situation with a Special Focus on Australia and Kenya. Water 2016, 8, 149. [CrossRef]

2. Ghisi, E.; Schondermark, P.N. Investment Feasibility Analysis of Rainwater Use in Residences. Water Resour. Manag. 2013, 27, 2555-2576. [CrossRef]

3. Fernandes, L.F.S.; Terêncio, D.P.S.; Pacheco, F.A.L. Rainwater harvesting systems for low demanding applications. Sci. Total Environ. 2015, 529, 91-100. [CrossRef] [PubMed]

4. ABNT (Associação Brasileira de Normas Técnicas). Água de chuva-Aproveitamento de coberturas em áreas urbanas para fins não potáveis-Requisitos. In Rainwater-Harvesting from Roofs in Urban Areas for Non-Potable Uses-Requirements; NBR 15527; ABNT: Rio de Janeiro, Brazil, 2019. (In Portuguese)

5. Zhang, X.; Wu, Y.; Shen, L. Embedding "green" in project-based organisations: The way ahead in the construction industry? J. Clean. Prod. 2015, 107, 420-427. [CrossRef]

6. Pessarelo, R. Estudo exploratório quanto ao consumo de água na produção de obras de edifícios: Avaliação e fatores influenciadores. In Study on Water Consumption in the Production of Building Works: Evaluation and Influencing Factors; Escola Politécnica, Universidade de São Paulo: São Paulo, Brazil, 2008. (In Portuguese)

7. Santos, C.P.; Silva, S.R.; Cerqueira, C.A. Water consumption in construction sites in the city of Recife/PE. Electron. J. Geotech. Eng. 2015, 20, 1711-1726.

8. Souza, T.D.; Ghisi, E. Harvesting rainwater from scaffolding platforms and walls to reduce potable water consumption at buildings construction sites. J. Clean. Prod. 2020, 258, 120909. [CrossRef]

9. McCormack, M.; Treloar, G.J.; Palmowski, L.; Crawford, R. Modelling direct and indirect water requirements of construction. Build. Res. Inf. 2007, 35, 156-162. [CrossRef]

10. Zhong, Y.; Wu, P. Economic sustainability, environmental sustainability and constructability indicators related to concrete-and steel-projects. J. Clean. Prod. 2015, 108, 748-756. [CrossRef]

11. Cimento Itambé. Água da Chuva para Produzir Concreto. É Possível? Rainwater to Produce Concrete. Is It Possible? 2015. Available online: http:/ / www.cimentoitambe.com.br/agua-da-chuva-para-produzir-concreto/. (accessed on 6 March 2018).

12. ABNT (Associação Brasileira de Normas Técnicas). Água para amassamento do concreto. In Water for Concrete Manufacture; NBR 15900; ABNT: Rio de Janeiro, Brazil, 2009. (In Portuguese) 
13. Bedoya-Montoya, C.M.; Medina-Restrepo, C.A. El concreto elaborado con aguas lluvia como aporte ambiental desde la construcción. [Concrete Made with Rainwater as an Environmental Contribution from Construction]. Revista Facultad de Ingenieria 2016, 25, 31-39. (In Spanish) [CrossRef]

14. INMET. Instituto Nacional de Meteorologia, National Institute of Meteorology. 2018. Available online: http:/ /www.inmet.gov.br. (accessed on 30 August 2018). (In Portuguese)

15. Ghisi, E.; Cordova, M.M. Netuno 4. Computer programme. Universidade Federal de Santa Catarina, Departamento de Engenharia Civil. 2014. Available online: http:/ / www.labeee.ufsc.br/ (accessed on 7 February 2021). (In Portuguese).

16. Ghisi, E. Parameters Influencing the Sizing of Rainwater Tanks. Water Resour. Manag. 2010, 24, 2381-2403. [CrossRef]

17. IBGE. Instituto Brasileiro de Geografia e Estatística, 2018. Brazilian Institute for Geography and Statistics. Available online: http:/ / www.ibge.gov.br. (accessed on 2 October 2018). (In Portuguese)

18. Maravas, A.; Pantouvakis, J. A New Approach to Studying Net Present Value and the Internal Rate of Return of Engineering Projects under Uncertainty with Three-Dimensional Graphs. Adv. Civ. Eng. 2018, 2018, 6108680. [CrossRef]

19. Mishan, E.J.; Quah, E. Cost-Benefit Analysis, 5th ed.; Routledge: New York, NY, USA, 2007.

20. ABNT (Associação Brasileira de Normas Técnicas). Concreto de Cimento Portland-Preparo, controle, recebimento e aceitaçãoProcedimento. In Portland Cement Concrete—Preparation, Control, Receivement and Acceptance—Procedure; NBR 12655; ABNT: Rio de Janeiro, Brazil, 2015. (In Portuguese)

21. ABNT (Associação Brasileira de Normas Técnicas). Agregados-Reatividade álcali-agregado. In Alkali-Aggregate Reaction; NBR 15577; ABNT: Rio de Janeiro, Brazil, 2018. (In Portuguese)

22. ABNT (Associação Brasileira de Normas Técnicas). Cimento Portland-Determinação dos tempos de pega. In Portland Cement —Determination of the Concrete Setting Time; NBR 16607; ABNT: Rio de Janeiro, Brazil, 2017. (In Portuguese)

23. ABNT (Associação Brasileira de Normas Técnicas). Concreto-Procedimento para moldagem e cura de corpos de prova. In Concrete-Procedure for Molding and Curing Concrete Specimens; NBR 5738; ABNT: Rio de Janeiro, Brazil, 2015. (In Portuguese)

24. ABNT (Associação Brasileira de Normas Técnicas). Concreto-Ensaio de compressão de corpos de prova cilíndricos. Concrete —Strength Compression Test in Cylindric Concrete Specimens; NBR 5739; ABNT: Rio de Janeiro, Brazil, 2018. (In Portuguese) 